\title{
Stimulation Democracy Value Using Just Community Approach for Youth Offender
}

\author{
D Sukma ${ }^{1}$, A Ananda ${ }^{2}$, N Gistituati ${ }^{3}$ D Daharnis ${ }^{4}$ \\ Departement of Guidance and Counseling, Universitas Negeri Padang, Air Tawar, Padang, \\ Indonesia ${ }^{1,4}$ \\ Departement of Social Science, Universitas Negeri Padang, Air Tawar, Padang, Indonesia ${ }^{2}$ \\ Departement of Education Administration, Universitas Negeri Padang, Air Tawar, Padang, \\ Indonesia $^{3}$ \\ \{ sukmadina@fip.unp.ac.id ${ }^{1}$, ananda@fis.unp.ac.id², ng@fip.unp.ac.id ${ }^{3}$, daharnis@konselor.org $\left.{ }^{4}\right\}$
}

\begin{abstract}
Youth offender was an adolescent that categorized as juvenile delinquency that offends the law and face justice that forces them to live in child prison as judgment law and decision. Child prisoners got religious advice periodically one day per week then got legal awareness in special moments. In conventional ways, the educational method used was teacher-centered, which students through in a passive way. Nonetheless, in child prison in West Sumatera, there is no significant model of guidance process to support moral development and increase democracy value. However, democracy is a basic value to power up human development such as moral thinking, ego controlling, and behavior development. It proved by the existence of recidivists and its means that the guidance process didn't reach the goal-to made moral and behavior changes in youth offender. Kohlberg suggested just community to support their basic problem-lack of moral development-and develop democracy value in a group format that power-up student involvement. This study tries to describe youth offender's perceptions about educational by using the School Culture Scale (SCS) and collecting the educational background of the youth offenders. The result of this study tries to design just a community model which suitable to implemented in child prison West Sumatera Indonesia.
\end{abstract}

Keywords: Democracy Value, Just Community Approach, Youth Offender. 


\section{Introduction}

Youth offender is the teenager that has offend to law and face justice that forces them to live in child prison as judgment law. According to Kohlberg's theory, they lack moral development used to be a conventional phase or post-conventional phase. On the other hand, they may also have a character's problems that worsen their behavior.

According to the constitution, they through three-phase in jail. First, the orientation phase, which tries to made them adjust to jail's situation. In this phase, they also got legal awareness, religious awareness, nation, and state awareness, and some intellectual practice. Second, coaching phase which practices them of many skills that will be needed when they already get out of the jail. Three-phase is assimilation this phase is made them ready to face their independent days.

The orientation phase is very important to fix their moral thinking and building their character by using many moral character education methods. Kohlberg already made some model such as moral discussion, and just community. Just the community already implemented in many countries and many institutions reach the goal successfully. In 1985 just community seed named Kibbutz model are prove the effectiveness by Kohlberg himself and many colleagues. After implementing this method to 92 adolescents, there are moral development improve stage [1]. In 1992, Georg Lind et all implemented just community to 395 senior high school students in North-Rhine Westfalia German and by using Sociomoral Reflection Measure there were improved moral thinking. Just the community approach develops or supports the moral development of the student through the practices, organization, and culture of the school [2]. There are questions that come: what design in just community model which suitable to develop democracy value's youth offender in child prison West Sumatera Indonesia?.

\section{Related Work}

Just Community is a method of character education by Lawrence Kohlberg and his colleagues who created it because of dissatisfaction with his own phenomenal work of "moral discussion". Unlike moral discussions that focus on individual moral reasoning, Just Community stresses the culture that affects the moral life and discipline that takes place in a school that is the school culture called by John Dewey as the "hidden curriculum". School cultures include the mindset, attitudes and behaviors of students, teachers, principals and other school personnel formed through interactions that are bound by the various rules, norms, morals, and ethics prevailing within the school.

Kohlberg founded the first "School of Community" first in the spring of 1974 in the town of Cambridge, with the result that the school produced the following principles: 1) the school will be managed with direct democracy. All major issues will be discussed and decided on weekly community meetings where all members (ie students and teachers) have a voice, 2) in addition, there will be a number of committees to be filled by students, teachers and parents 3) students and teachers have the same basic rights, including freedom of expression, respect for others and free from physical harm or humiliation [3].

The Just Community model has two main objectives: producing children's moral development and to change the moral atmosphere of the school into a moral community. Although the purpose of developing children's moral reasoning is the ultimate goal of the Just Community model, this goal is achieved by creating a conducive moral atmosphere from the perspective of fair community theory as the ultimate goal [3]. Using this model of moral 
development and student responsibility is driven through the organization, practice, and culture of the school itself.

Based on the above description we can say that the objectives of Just Community are: 1) creating creativity and adaptation to the rules of all children; 2) stimulate children's moral reasoning abilities; 3) maintain a balance between moral reasoning and moral action; 4) train moral empathy and encourage pro-social commitment; and 5) developing a solid value system based on tolerance and openness.

The obstacles faced in running Just Community are then realized by the followers of Kohlberg can hinder the achievement of the above goals. Without attempting to undermine the Just Community, Oser (1996: 5) tries to formulate "minimum moral goals" or the minimal moral goals that can be achieved through Just Community which can be described as follows: 1) stimulate moral development at a higher stage; 2) to make children and adolescents more sensitive to moral issues such as security, justice, honesty, tolerance and providing space for expressing moral feelings; 3) support and encourage moral and prosocial behavior; 4) maintain the moral atmosphere of negative behavior that becomes an important lesson; and 5) provide children with opportunities to build ethical knowledge whose actions are a reflection of selfassessment and others.

In essence, the Just Community model is a method of character education based on two psychological approaches that approach cognitive psychology and community psychology approach. The cognitive psychological approach used is related to the flow used by Kohlberg in formulating stages of moral development. Cognitive psychology sees an individual perspective as the main source of how humans create their world including differentiating between good and bad.

Meanwhile, the community psychology approach differs from the traditional view which assumes the relations of the perpetrator and its environment (P, E) as an entity. This approach gives special attention to the relations $(\mathrm{P}, \mathrm{E})$ contained in the social context or social order society. Community psychology views that individual behavior can not be separated from the context in which the behavior is emerging then anything contained in an environment or community will affect the behavior of individuals or members who reside in it. Hence the psychology of the community in looking at individual issues and social issues focuses attention not only on how individuals are but on how the environment or community lies for its members.

\section{Method}

\subsection{Research Design}

The descriptive research design was employed to investigate the youth offender's perceptions about educational and democracy opportunities and guidance process in child prison in West Sumatra Province, Indonesia.

\subsection{Population of Study}

The population of the study of youth offenders has been living in a child prison minimum of 1 month. 


\subsection{Instrument}

Data for the study was observation guidance, interview guidance, obtained through the administration of copies of a structured questionnaire about youth offenders about the guidance process in Jail. The structured questionnaire from the qualitative work of Power, Higgins, and Kohlberg [3] named the School Culture Scale [4].

One of the aspects is democratic and educational opportunities. This aspect contained 6 item are: kids get a good education and learn a lot; kids learn to become more responsible and care for other people; kids learn how to speak up and express opinions; kids learn how to listen to other people's ideas better; kids learn how to take other people's points of view; and tutor give kids a say in decisions about prison rules.

The questionnaire was self-administered after the purpose of the survey and instruction on the questionnaire was explained. The researcher paid a series of visits to Jail. The questionnaire contained items measured using a 5 - point Likert scale with responses ranging from $1=$ false, $2=$ often false; $3=$ sometimes true, sometimes false; $4=$ often true; and $5=$ true. The answer was nominally scored and thereafter transformed into variables, while items were scored as follows for positively worded items.

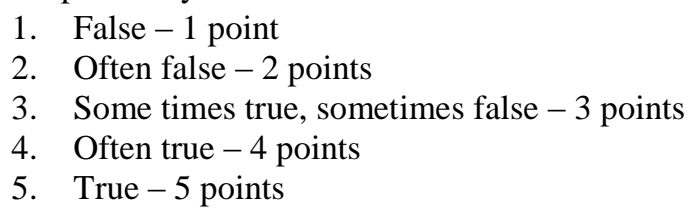

\subsection{Sampling Procedure}

The study employed purposive and accidental sampling techniques. The purposive sampling technique was used to purposively select only youth offenders at least have been living in jail for 1 month and only males. There 32 youth offenders living in Jail but only 20 have been living a minimum 1 month.

\subsection{Data Analysis}

Data obtained from the administered questionnaire were analyzed using tables and simple percentages.

\section{Results And Discussion}

\subsection{Education Background of Youth Offender}

Youth offender education background varied from no school (3\%), primary school (53\%), secondary school (28\%), and senior high school (16\%) that shows in Table 1.

Table 1: Youth Offender's Education Background

\begin{tabular}{cccccc}
\hline Education Background & Age & Gender & $\sum$ & \multicolumn{2}{c}{ Percentage } \\
\hline \multirow{2}{*}{ Senior High School } & 17 & $\mathrm{M}$ & 3 & 9 & \multirow{2}{*}{16} \\
\cline { 2 - 5 } & 16 & $\mathrm{M}$ & 2 & 7 & \\
\hline
\end{tabular}




\begin{tabular}{ccccccc}
\hline \multirow{3}{*}{ Secondary School } & 17 & M & 5 & 16 & \multirow{2}{*}{28} \\
\cline { 2 - 5 } & 16 & M & 4 & 12 & \\
\hline \multirow{3}{*}{ Primary School } & 18 & M & 4 & 12 & \\
& 17 & M & 7 & 23 & \multirow{2}{*}{53} \\
\cline { 2 - 5 } & 16 & M & 4 & 12 & \\
\cline { 2 - 5 } & 15 & M & 2 & 6 & \\
\hline No School & 17 & M & 1 & 3 & 3 \\
\hline
\end{tabular}

\subsection{Youth Offender's perception of democratic and educational opportunities}

Through the administration of the youth offender's perception of the democratic and educational opportunities questionnaire. Means score 4,4 (index: 5) then data was analyzed by using 5 categories very negative, negative, neutral, positive, and very positive, analyzed result shows in Table 2 below.

Table 2: Youth Offender's Perception of democratic and educational opportunities

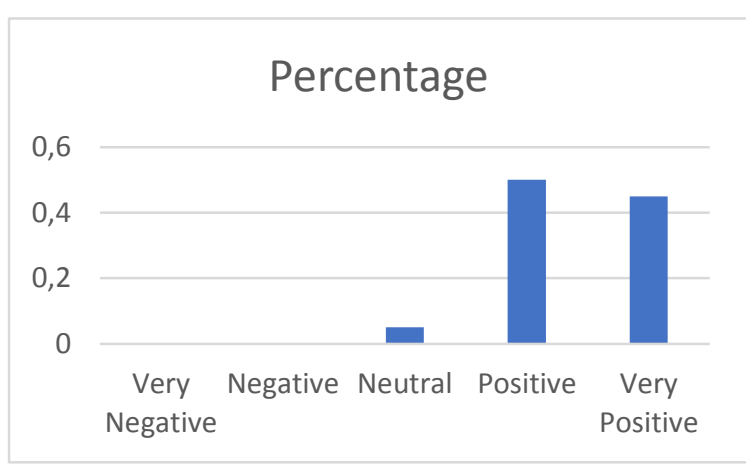

Table 2 shows that youth offender perception of democratic and educational opportunities is varied in neutral, positive and very positive.

Table 3: Youth Offender's Perception of democratic and educational opportunities per item

\begin{tabular}{ccccccccc}
\hline \multirow{2}{*}{ Rsp } & \multicolumn{6}{c}{ Score per item } & \multicolumn{1}{c}{$\sum$} & Category \\
\cline { 2 - 8 } & $\mathbf{1}$ & $\mathbf{2}$ & $\mathbf{3}$ & $\mathbf{4}$ & $\mathbf{5}$ & $\mathbf{6}$ & & \\
\hline 1 & 4 & 4 & 4 & 5 & 5 & 4 & 26 & Very positive \\
\hline 2 & 3 & 4 & 4 & 4 & 4 & 3 & 22 & Positive \\
\hline 3 & 4 & 3 & 3 & 3 & 3 & 1 & 17 & Neutral \\
\hline 4 & 5 & 5 & 3 & 3 & 3 & 3 & 22 & Positive \\
\hline 5 & 5 & 4 & 3 & 4 & 4 & 3 & 23 & Positive
\end{tabular}




\begin{tabular}{ccccccccc}
\hline 6 & 5 & 5 & 3 & 3 & 3 & 3 & 22 & Positive \\
\hline 7 & 4 & 4 & 4 & 4 & 5 & 5 & 26 & Very positive \\
\hline 8 & 5 & 3 & 3 & 4 & 3 & 3 & 21 & Positive \\
\hline 9 & 5 & 5 & 5 & 5 & 5 & 1 & 26 & Very positive \\
\hline 10 & 5 & 4 & 4 & 3 & 3 & 3 & 22 & Positive \\
\hline 11 & 5 & 3 & 4 & 5 & 5 & 1 & 23 & Positive \\
\hline 12 & 5 & 5 & 4 & 5 & 4 & 3 & 26 & Very positive \\
\hline 13 & 5 & 5 & 4 & 5 & 5 & 4 & 28 & Very positive \\
\hline 14 & 4 & 4 & 3 & 3 & 4 & 3 & 21 & Positive \\
\hline 15 & 5 & 4 & 5 & 4 & 5 & 5 & 28 & Very positive \\
\hline 16 & 5 & 5 & 5 & 5 & 4 & 4 & 28 & Very positive \\
\hline 17 & 5 & 5 & 5 & 5 & 5 & 5 & 30 & Very positive \\
\hline 18 & 4 & 5 & 5 & 5 & 5 & 4 & 28 & Very positive \\
\hline 19 & 2 & 3 & 3 & 3 & 5 & 5 & 21 & Positive \\
\hline 20 & 5 & 4 & 4 & 5 & 3 & 3 & 24 & Positive \\
\hline
\end{tabular}

Youth offender's perceptions about democracy and educational opportunities are varied into positive and very positive. But for the item 6 (tutor give kids a say in decisions about prison rules), there are $3(15 \%)$ respondents that have a minimum score (1) and 9 (45\%) respondent has a middle score (3). This means that youth offender has varied perception through opportunities to say in decisions about prison rules.

\subsection{Education of Youth Offender and Its Implications to Instructional Method}

More than half (53\%) of youth prisoners only have primary school educational background. Their ages between 14 until 18 years old most of them are a dropout from their primary school. Only a few $(16 \%)$ of them already got to senior high school. It means that their academical experience is very low. They not used to read, write, ask, answer, counting and much academical skill. So the method must be something that suitable for the primary school academical level. This can be effective in their ability to focus. Jacobs et_al (1987: 104) suggest to using visual aids and having members write or draw something are excellent ways to get members focused. The activities that can be used is by use posters, charts, or diagram relevant to the topic, use a chalkboard or a large pad to list item, have members to draw something, put a large piece of paper on the floor, etc.

Based on the interview process by collecting data, youth offenders haven't good communication skills. Take a lot of time reaction to answer an only simple question. Lack of communication skills was the impact of the minimum provision of education. So the method 
must be learner-centered to maximize high standards of learning and motivation. The learnercentered are focused on knowing and understanding each learner in a way to an understanding of the learning process itself. [5]. This perspective is knowing and respecting individual learners by practice, research and experience about learning itself.

\subsection{Analysis of the Youth Offender Exposed to Group Counseling}

In the orientation phase, youth offenders through "psychological shaking" from liberty and happiness because they were separated from a family that gives them love and care. Then they have to spend his life living in a child prison. Parents or family time to visit are restricted only about 15 minutes per day. Meanwhile, they come from far away places that need time, energy and money. Lack of visits from parents or family shows that youth offenders need for love from parents or any adults as parents substitutes. So, it means that the youth offenders need more social interaction with warden prison or the other prisoner to fulfill the need of love.

Lack of liberty caused many psychological problems such as depression and it more complex with an adolescent that still has a strong attachment to their parents. In this phase, they start to reduce parent attachment and looking for support from their peer group. Lack of parental support impact a lot of depressive symptoms and the onset of major depression. In contrast, initial depressive symptoms and major depression will decrease on peer support rather than parental support [6]. It means we can empowering peer support of youth offender to fulfill their need of love who lives almost 24 hours per day with their peer group.

Group therapy or group counseling for youth offenders in child prison is one of the best methods to build peer support. Research in many prisons has been implemented by using group psychotherapy and proved that combined therapy (group and individual) is stronger than individual only [7]. Group gave them more attention to fulfilling the psychological needs of youth prisoners and gave them 'opportunities' to experiment and feel that they were being understood by the groups [8].

\subsection{The implication of Just Community to Youth Offender}

Kohlberg suggest Just Community to the prison situation the principles of moral development derived from the study of moral development in children. Institutions which provide an experience such democracy, would push moral development for youth offenders. In order to provide democratic situations that created interaction between staff and youth offenders discuss moral issues and where the staff is sufficiently aware of the nature of moral development then youth offenders upward levels of moral thinking [9].

Just community creates a real-life experience of making and running rules that up war decision-making skills. With this realization came the "just community" approach to moral education, base on Aristotle's own understanding of practical wisdom. Just the community derived from the theories of Dewey and Piaget. Just a community approach was to create the governance of a small school community by the student, teacher, and staff participation would stimulate the growth of moral reasoning [3].

In order to implement just community, members commit to participating in democracy in building a moral community that is very important matters. Members in every community meeting, they commit to regulated norms and reflect moral ideals. These shared norms to the 
product of democratic deliberation in community meetings [10]. If the commitment didn't exist, just community become very difficult to reach the success. By sharing lived experience, each members will encourages group solidarity and identification. But group identification is not simply awareness that one is a member of a group, but rather that one is responsible for the group. The responsible self was a communal self that takes on obligations and duties as a result of a shared commitment to group norms [10].

Just community are need by for youth offender because they lack of moral development and they need peer support from their peer group. Therefore they live almost 24 hour per day with peer group. Just community is a learner-centered should using many media such as visual, chalkboard or list to establish their focus to the moral topic been discuss. The discussion held by a group that already formed before and the formation of group are heterogeneous so the discussion will produce a group dynamic.

The Just Community model develops judgment and decision making through a practice called deliberative democracy. This process aims to achieve practical consensus as much as possible through an ongoing dialogue in which all parties are encouraged to participate. This approach fosters a sense of responsibility by encouraging students to get acquainted with their group members and as well as understanding moral values and through deliberation

The Just Community model is directed not only to promote children's moral reasoning, but to encourage all the moral components of the child to function (Narváez, D., \& Rest, J., 1995). From the outset, Just Community's approach is understood as a bridge between consideration and moral action as it examines the real interactions between students and teachers in schools. Just Community maintains moral sensitivity by bringing issues of mutual concern to get the attention of teachers and students in their weekly meetings.

Just a Community brings together a group of about a hundred students and teachers for an hour or more each day for two weekly meetings that last at least one hour of study. Most decisions affecting community life and discipline are made democratically in the weekly compulsory community meetings in which students and teachers have the same voice. Teachers and students meet weekly in the advisory group to prepare for community meetings. These programs are implemented with a strong commitment to developing a common moral life characterized by seeking justice and building group solidarity. Teachers in the Just Community program are challenged to demonstrate moral leadership to achieve common goals while engaging student involvement.

In community meetings, students and teachers determine the rules and norms in guiding their common life. Students and teachers are expected to help each other meet common expectations. When a violation occurs, a party or some guilty party is brought before the whole community in a community meeting. The Just Community model also encourages the implementation of the agreed-upon goal together.

The agenda for community meetings will be discussed and small groups on various issues and try to reach consensus or agreement by majority and minority proposals to be brought to the next day's meeting. All these meetings serve as a context for moral discussion and achieve a sense of community solidarity or to create a moral atmosphere through democratic governance practices (ie, reaching fair decisions, implementing these decisions and, where appropriate, changing their decisions democratically). Direct participatory democracy, in turn serves to protect the rights of students, limits the power of group solidarity to impose the conceptions proposed. 
The role of teachers in regular classroom moral discussions, they can function as facilitators, but in Just Community schools they must function as supporters, in particular supporting moral, justice and community content. Thus teachers serve as moral leaders by supporting their own views within one person's boundaries, one voice and engaging with what "what" the students decide to do and the "why" they decide to do.

Based the description, so it can be concluded Just Community has three main components that distinguish it from other models:

a) Arrange collective rules democratically, rules relating to group interests are collectively democratically arranged in which each student has the right to express his opinion on what rules are best for the group. Arrangement of rules together meant that all students feel have rules that are made. This is very important in the disciplinary process of students because the feeling of having rules will encourage them to always obey them. In addition, it is not uncommon for social problems that arise among students due to the lack of clear rules, inadequate or lack of local regulations such as: prohibited from calling other than name, prohibited to use the property of others without asking permission first, prohibited speaking without mentioning the nickname to the other person and other rules.

b) Sharing personal matters of participants, in meetings it is possible for students to share their personal or related issues with group issues to be discussed in groups. Within-group members' issues are discussed to seek solutions from other members and facilitators.

c) The facilitator has a voice-restricted right, in contrast to Lawrence Kohlberg's previous work of moral discussion in which teachers or facilitators may not share opinions, make conclusions or commit to this method, teachers have a voice-restricted right to voice and is obliged to state its commitment to the group. With the opportunity for the teacher or facilitator to speak up or express his opinion then he will be able to provide direction, guidance in the group process so that the discussion goes in the right direction. A commitment statement from the teacher or facilitator is equally important in following up the outcome of the meeting as the follow-up of the meeting result is very important to foster the students' interest to attend the next meetings.

\section{Conclusions}

Youth offender who offend to law, according to Kohlberg's theory, they lack moral development used to be a conventional phase or post-conventional phase. On the other hand, they may also have character's problem that worsens their behavior. In democratic value, there is one offender are in the middle. It means that democratic values did not develop as our expectations. In friendly or communicative value, there is two offenders are in the middle. So the method should be learner-centered to reach high standards of the learning process and building democratic values.

Democratic education is a powerful stimulus to support the development of cognitive, ego, social, political, and moral development [11]. So democratic is one of the important values that need to educate on youth offenders.

Just community for youth offenders must be learner-centered and using many media such as visual, chalkboard or list to establish their focus on the moral topic been discuss. The discussion 
held by a group that already formed before. The formation of groups is heterogeneous so the discussion will produce a group dynamic.

\section{References}

[1] J. R. Snarey, J. Reimer, and L. Kohlberg, "Development of social-moral reasoning among Kibbutz adolescents: A longitudinal cross-cultural study.," Dev. Psychol., vol. 21, no. 1, p. 3, 1985.

[2] F. C. Power and A. Higgins-D'Alessandro, "The just community approach to moral education and the moral atmosphere of the school," Handb. moral character Educ., pp. 230-247, 2008.

[3] F. C. Power, A. Higgins, and L. Kohlberg, "Lawrence Kohlberg's Approach to Moral Education.” Columbia University Press, New York, 1991.

[4] A. Higgins-D'Alessandro and D. Sadh, "The dimensions and measurement of school culture: Understanding school culture as the basis for school reform," Int. J. Educ. Res., vol. 27, no. 7, pp. 553-569, 1998.

[5] B. L. McCombs and J. S. Whisler, The Learner-Centered Classroom and School: Strategies for Increasing Student Motivation and Achievement. The Jossey-Bass Education Series. ERIC, 1997.

[6] E. Stice, J. Ragan, and P. Randall, "Prospective relations between social support and depression: differential direction of effects for parent and peer support?," J. Abnorm. Psychol., vol. 113, no. 1, p. 155, 2004.

[7] M. Khodayarifard, M. Shokoohi-Yekta, and G. E. Hamot, "Effects of individual and group cognitive-behavioral therapy for male prisoners in Iran," Int. J. Offender Ther. Comp. Criminol., vol. 54, no. 5, pp. 743-755, 2010.

[8] P. van der Helm, M. Klapwijk, G. Stams, and P. van der Laan, “'What works' for juvenile prisoners: the role of group climate in a youth prison," J. Child. Serv., vol. 4, no. 2 , pp. $36-48,2009$.

[9] L. Kohlberg, K. Kauffman, P. Scharf, and J. Hickey, "The just community approach to corrections: A theory," J. Moral Educ., vol. 4, no. 3, pp. 243-260, 1975.

[10] D. K. Lapsley and P. C. Stey, "Moral self-identity as the aim of education," Handb. moral character Educ., pp. 30-52, 2008.

[11] R. Mosher, Preparing for Citizenship: Teaching Youth To Live Democratically. ERIC, 1994. 